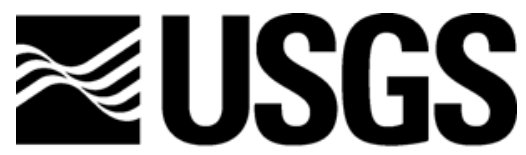

science for a changing world

In Cooperation with the U.S. Forest Service and Colorado Geological Survey

\title{
Well Construction Information, Lithologic Logs, Water Level Data, and Overview of Research in Handcart Gulch, Colorado: An Alpine Watershed Affected by Metalliferous Hydrothermal Alteration
}

By Jonathan Saul Caine', Andrew H. Manning', Philip L. Verplanck', Dana J. Bove', Katherine Gurley Kahn', and Shemin $\mathrm{Ge}^{2}$

1 U.S. Geological Survey, Geological Discipline, Denver, CO.

${ }^{2}$ University of Colorado, Department of Geological Sciences, Boulder, CO.

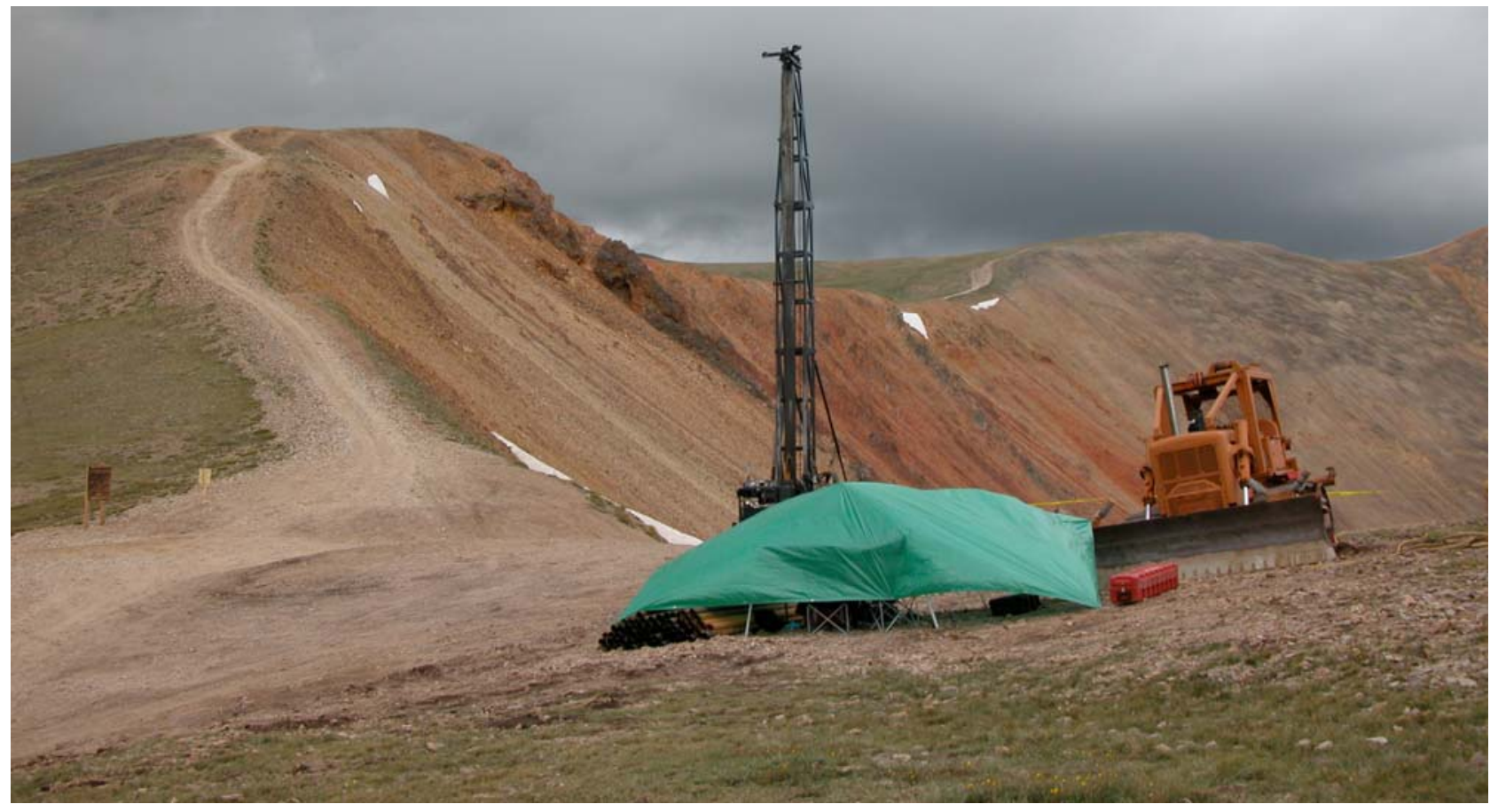

Open-File Report 2006-1189

U.S. Department of the Interior

U.S. Geological Survey 


\section{U.S. Department of the Interior DIRK KEMPTHORNE, Secretary}

\section{U.S. Geological Survey \\ P. Patrick Leahy, Acting Director}

U.S. Geological Survey, Reston, Virginia 2006

For product and ordering information:

World Wide Web: http://www.usgs.gov/pubprod

Telephone: 1-888-ASK-USGS

For more information on the USGS - the Federal source for science about the Earth, its natural and living resources, natural hazards, and the environment:

World Wide Web: http://www.usgs.gov

Telephone: 1-888-ASK-USGS

Any use of trade, firm, or product names is for descriptive purposes only and does not imply endorsement by the U.S. Government

Although this report is in the public domain, permission must be secured from the individual copyright owners to reproduce any copyrighted material contained within this report.

Suggested citation: Caine, J.S. and Others, 2006, Well Construction Information, Lithologic Logs, Water Level Data, and Overview of Research in Handcart Gulch, Colorado: An Alpine Watershed Affected by Metalliferous Hydrothermal Alteration: U.S. Geological Survey Open-File Report 2006-1189, 14 pp., < http://pubs.usgs.gov/of/2006/1189/ >. 


\section{Contents}

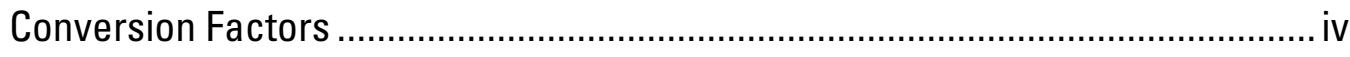

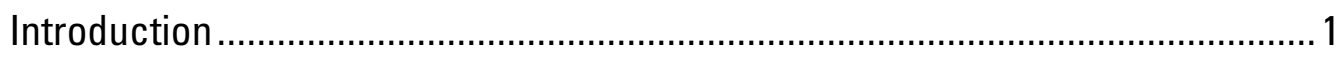

Overview of Research in Handcart Gulch........................................................ 2

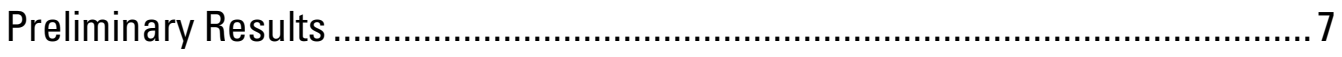

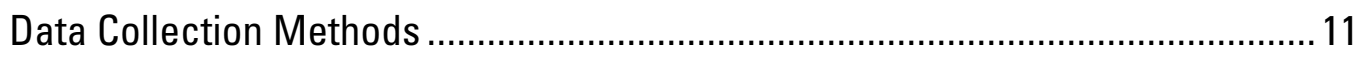

Spreadsheet Data Format, Well Access, and Contact Information........................ 12

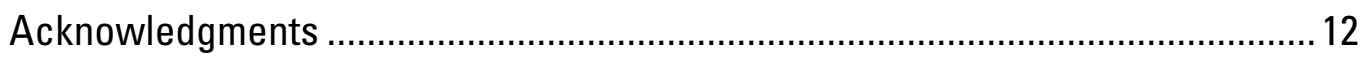

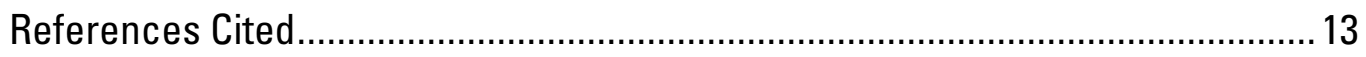

\section{Figures}

1. Location of Handcart Gulch in Colorado .......................................................

2. Well location map .................................................................................. 4

3. Photograph of the Red Cone mountain and pyrite deposits.............................. 4

\section{Tables}

Data File Spreadsheet (click this link to download)........< HandcartWellData.xls > 


\section{Conversion Factors}

\section{SI to Inch/Pound}

\begin{tabular}{|c|c|c|}
\hline Multiply & By & To obtain \\
\hline \multicolumn{3}{|c|}{ Length } \\
\hline meter $(\mathrm{m})$ & 3.281 & foot (ft) \\
\hline kilometer (km) & 0.6214 & mile (mi) \\
\hline \multicolumn{3}{|c|}{ Area } \\
\hline square meter $\left(\mathrm{m}^{2}\right)$ & 0.000247 & acre \\
\hline square kilometer $\left(\mathrm{km}^{2}\right)$ & 0.386 & square mile $\left(\mathrm{mi}^{2}\right)$ \\
\hline \multicolumn{3}{|c|}{ Volume } \\
\hline liter (L) & 0.264 & gallon (gal) \\
\hline cubic meter $\left(\mathrm{m}^{3}\right)$ & 264.2 & gallon (gal) \\
\hline \multicolumn{3}{|c|}{ Flow rate } \\
\hline cubic meter per second $\left(\mathrm{m}^{3} / \mathrm{s}\right)$ & 70.07 & acre-foot per day (acre-ft/d) \\
\hline liter per second $(\mathrm{L} / \mathrm{s})$ & 15.85 & gallon per minute (gal/min) \\
\hline \multicolumn{3}{|c|}{ Hydraulic conductivity } \\
\hline meter per second $(\mathrm{m} / \mathrm{s})$ & 0.00002835 & foot per day (ft/d) \\
\hline \multicolumn{3}{|c|}{ Hydraulic gradient } \\
\hline meter per kilometer $(\mathrm{m} / \mathrm{km})$ & 5.2798 & foot per mile (ft/mi) \\
\hline \multicolumn{3}{|c|}{ Transmissivity } \\
\hline meter squared per second $\left(\mathrm{m}^{2} / \mathrm{s}\right)$ & 10.76 & foot squared per second $\left(\mathrm{ft}^{2} / \mathrm{s}\right)$ \\
\hline
\end{tabular}

Temperature in degrees Celsius $\left({ }^{\circ} \mathrm{C}\right)$ may be converted to degrees Fahrenheit $\left({ }^{\circ} \mathrm{F}\right)$ as follows: ${ }^{\circ} \mathrm{F}=\left(1.8 \times{ }^{\circ} \mathrm{C}\right)+32$

Temperature in degrees Fahrenheit $\left({ }^{\circ} \mathrm{F}\right)$ may be converted to degrees Celsius $\left({ }^{\circ} \mathrm{C}\right)$ as follows: ${ }^{\circ} \mathrm{C}=\left({ }^{\circ} \mathrm{F}-32\right) / 1.8$

Vertical coordinate information is referenced to the North American Vertical Datum of 1927 (NAD 27)

Horizontal coordinate information is referenced to the North American Datum of 1927 (NAD 27)

Altitude, as used in this report, refers to distance above mean sea level. 


\title{
Well Construction Information, Lithologic Logs, Water Level Data, and Overview of Research in Handcart Gulch, Colorado: An Alpine Watershed Affected by Metalliferous Hydrothermal Alteration
}

\author{
By Jonathan Saul Caine, Andrew H. Manning, Philip L. Verplanck, Dana J. Bove, \\ Katherine Gurley Kahn, and Shemin Ge
}

\section{Introduction}

Integrated, multidisciplinary studies of the Handcart Gulch alpine watershed provide a unique opportunity to study and characterize the geology and hydrology of an alpine watershed along the Continental Divide. The study area arose out of the donation of four abandoned, deep mineral exploration boreholes to the U.S. Geological Survey for research purposes by Mineral Systems Inc. These holes were supplemented with nine additional shallow holes drilled by the U.S. Geological Survey along the Handcart Gulch trunk stream. All of the holes were converted into observation wells, and a variety of data and samples were measured and collected from each.

The motivation to study the geology and hydrology of Handcart Gulch is multifold. There is an absence of ground-water data in alpine environments worldwide. This is largely due to a lack of wells in alpine settings, which typically have sparse populations and pose significant challenges for access and drilling. However, there is growing recognition that mountains play a critical role in the hydrologic cycle in many parts of the world, capturing precipitation by orographic effect, storing water in snowpack and in mountain aquifers, and initiating transport of water from the surface to local and regional aquifers, and possibly even deeper to the upper crust of the Earth. In many cases understanding regional aquifer systems requires an understanding of ground-water flow 
in adjacent mountains where recharge occurs. Rapidly increasing population in mountainous areas has led to a greater utilization of mountain aquifers and a need to better understand their production capacity and vulnerability to contamination. Mineral deposits commonly occur in mountainous environments, resulting in mining-related as well as natural acid and trace metal loading to alpine surface and ground waters. Growing demand to improve water quality in affected mountain streams has created a need to understand the ground-water systems feeding these streams. Finally, the fundamental significance of water in geologic processes in the Earth's upper crust (i.e., orogenesis, metamorphism, and earthquake generation) has become increasingly clear, but the manner in which water enters and circulates to deep levels within the upper crust is poorly understood. Because mountains potentially serve as recharge zones and provide a gravitational driving force for these most-deeply circulating waters, processes controlling ground-water movement into and through all levels of mountain masses deserve further study.

This open-file report contains: (1) An overview of the research conducted to date in Handcart Gulch; (2) well location, construction, lithologic log, and water level data from the research boreholes; and (3) a brief synopsis of preliminary results. The primary purpose of this report is to provide a research overview as well as raw data from the boreholes. Interpretation of the data will be reported in future publications. The drill hole data were tabulated into a spreadsheet included with this digital open-file report.

\section{Overview of Research in Handcart Gulch}

Handcart Gulch is located in the southeastern portion of the Montezuma mining district of the central Colorado Rocky Mountain Front Range (fig. 1). It hosts a naturally acidic (pH 2.6- 


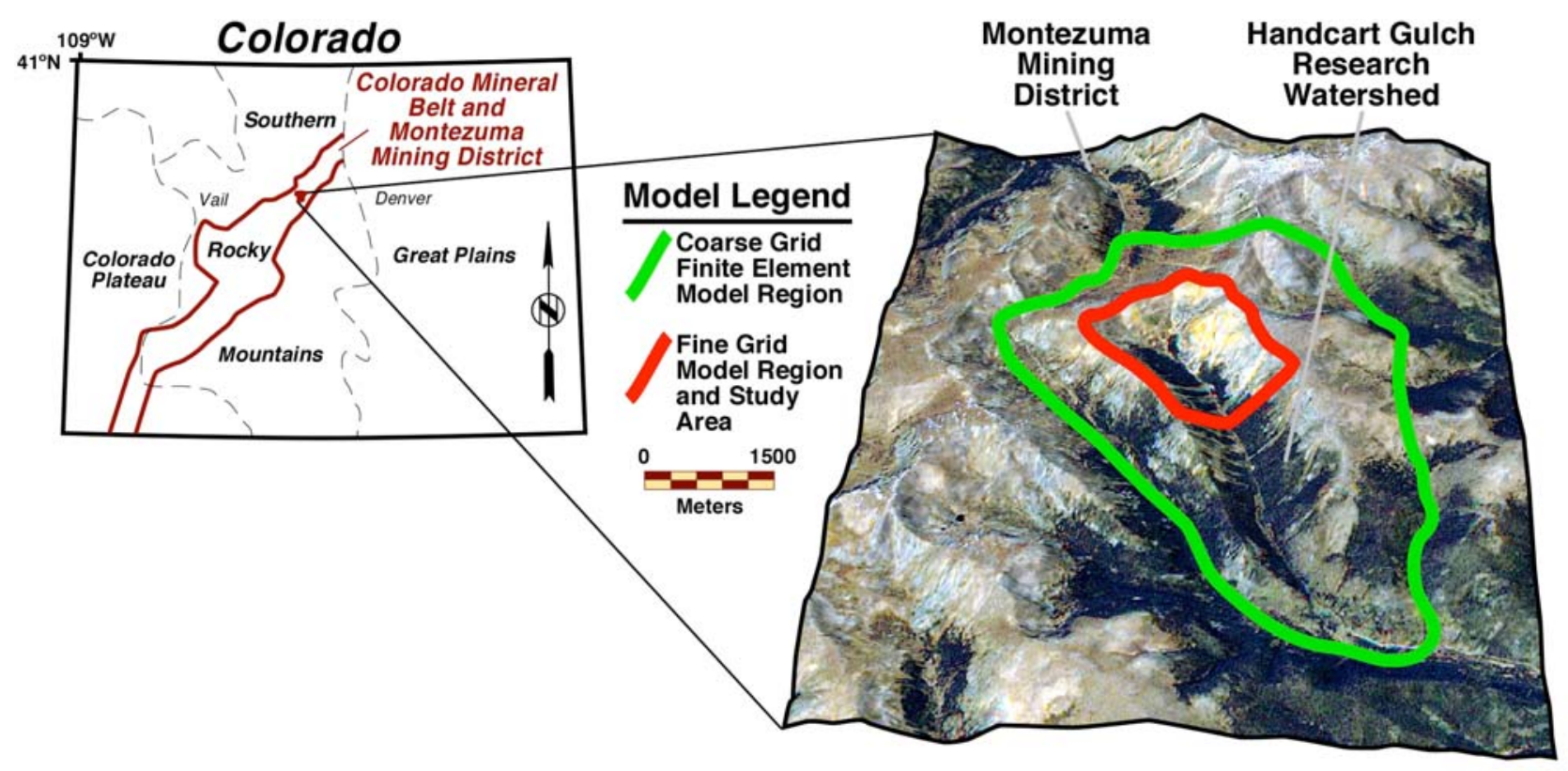

Figure 1. Location of Handcart Gulch with major physiographic province boundaries and the location of the study area within the Colorado Mineral Belt and Montezuma Mining District, which is characteristic of many such districts in the Mineral Belt. Also shown is a visible satellite image draped on a tilted digital elevation model. The image shows the extreme topographic relief $(2,700$ feet with a gradient of $\sim 0.1)$ and the red-orange weathering of the unmined pyrite deposit. The study area (red) and numerical ground-water flow model domains (red and green) are also shown.

4.6) stream with elevated metal concentrations due to the presence of a small, unmined, porphyryrelated molybdenite deposit. The mineral deposit lies within complexly fractured Precambrian metamorphic bedrock that consists of gneisses, schists, amphibolites, and granites that have been intruded by a series of Tertiary-age stocks and veins and was originally mapped by Lovering in 1935. The largest and most-well studied stock in the district is the Montezuma stock, a dominantly porphyritic quartz monzonite but which ranges to granite and aplite (Neuerburg and others, 1974). In Handcart Gulch small quartz monzonite porphyries crop out near Webster Pass and Red Cone (figs. 2 and 3). Along the valley floor, the bed of the trunk stream along most of its course is lined by ferricrete (iron-oxide-cemented alluvial and colluvial deposits). Another important feature of the northeastern part of the Handcart Gulch watershed is the presence of a rock glacier that shows evidence for recent motion. 


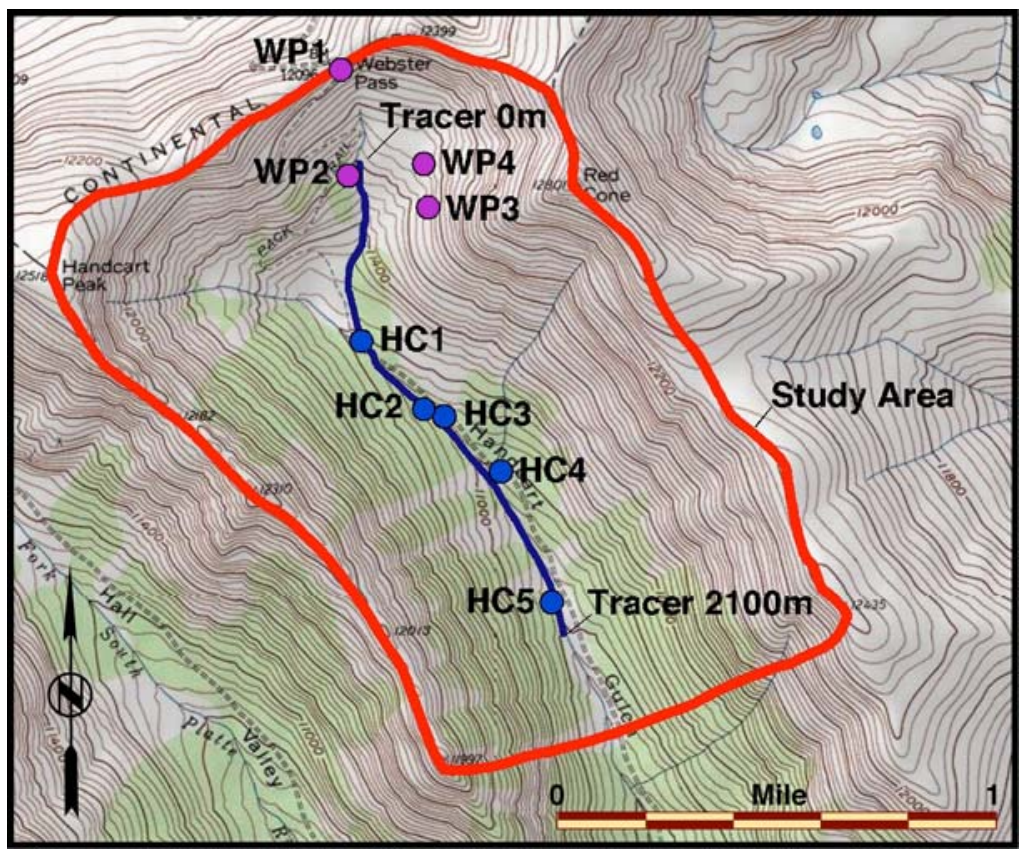

Figure 2. Topographic and study area map of Handcart Gulch, Colorado. The red line marks the primary $4.7 \mathrm{~km}^{2}$ study area and watershed divide. Observation well locations and the trunk stream reach along which the tracer dilution study was conducted also are shown. The deep WP wells are shown in purple, and the shallow HC well clusters are shown in blue. Note the location of Red Cone mountain, shown in Figure 3, along the northeast drainage divide.

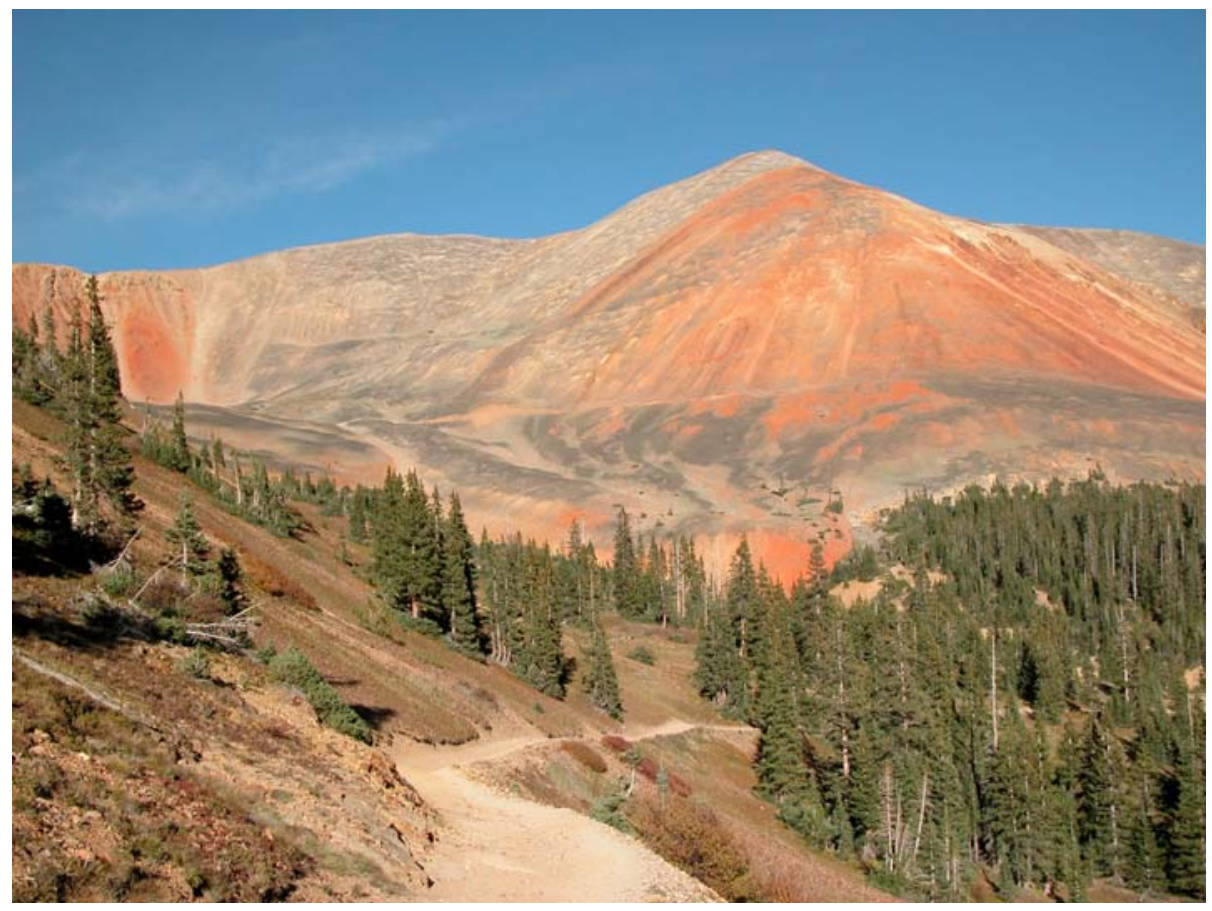

Figure 3. Red Cone Mountain in the upper reaches of Handcart Gulch, CO, 12,800 feet. Note the red staining from the oxidation of pyrite at concentrations of nearly ten percent of the rock mass. This is the primary and natural source of low pH water in the watershed. The upper road cuts across a major rock glacier and was excavated by Mineral Systems Inc. to drill the reconditioned exploration holes WP 3 and WP 4. 
The Montezuma district has a long mining history starting with an initial discovery of silver in 1864 (Lovering, 1935). Metals mined include silver, lead, zinc, and copper and base-metal ore minerals include galena, sphalerite, and tennantite-tetrahedrite (Botinelly, 1979). Molybdenite is also associated with the Tertiary porphyry stocks. Because of the proximity of the Climax deposit, this district has been explored for molybdenum mineralization. Within the upper portion of Handcart Gulch, no mining has occurred with the exception of one small adit with a waste-rock pile of approximately $300 \mathrm{ft}^{3}$. The watershed therefore provides a unique opportunity to monitor a natural acid-rock-drainage system in an unmined setting.

Various sulfide mineral deposits that are similar to that found in Handcart Gulch occur throughout the intermountain west in alpine watersheds, and commonly are sources of low-pH, metal-laden waters. Previous and ongoing investigations (e.g., Robinson, 1978; Caine, 2003; Caine and others, 2004; Manning and others, 2004; Verplanck and others, 2004; Kahn and others, 2005; Kahn, 2005; Naus and others, 2005; Johnson and Yager, 2006; Nordstrom and others, 2005) have focused on the ground water in these systems using various types of outcrop-scale geological data in concert with well data, and have given rise to several fundamental questions regarding groundwater flow in these environments and its role in transporting metals and acid. These include: (1) What are characteristic, fundamental hydraulic conditions in an alpine bedrock aquifer system given the extreme hydraulic head gradients and seasonal recharge rate variations, including watertable depths and fluctuations, recharge rates, bulk permeabilities, matrix and fracture porosities, circulation depths, and ground-water residence times? (2) Is the bulk permeability of the fractured bedrock sufficiently low, as is commonly assumed, to ignore contributions of bedrock-hosted ground water to streams? If not, is it typically high enough to demand the inclusion of the bedrock in watershed hydrologic models? (3) How does bedrock permeability vary spatially, particularly 
with depth, and what is the potential for ground water to exit the watershed in the subsurface? At what depth, if any, does the permeability become sufficiently low to justify placement of a basal no-flow boundary condition in a watershed ground-water flow model? (4) To what degree do discrete fracture networks control preferred flow paths as well as the bulk permeability structure of the ground-water flow system, and at what scale might the bulk permeability structure be treated as a continuum? (5) What are the fundamental geological, hydrological, and geochemical processes that control the rate at which acid and metals are introduced to the ground-water flow system? Do mountain ranges, particularly those that expose crystalline basement rocks, provide the initiation point and gravitational driving force for ground-water flow in the Earth's upper crust? We address these questions using the Handcart Gulch research watershed and wells.

In the summers of 2001 and 2002 the four deep wells in Handcart Gulch were drilled as mineral exploration boreholes by Mineral Systems Inc. with recovery of full drill cores. These wells were converted to observation wells as part of this study. They are located in the upper part of the watershed, the highest one at Webster Pass on the Continental Divide at 12,100 feet, and range in depth from 1,200 to 3,500 feet (fig. 2). In 2003 and 2004, Mineral Systems Inc. donated the boreholes to the U.S. Geological Survey. The U.S. Geological Survey reconditioned the boreholes for use as observation wells and secured well permits from the U.S. Forest Service and Colorado Office of the State Engineer. In the fall of 2003, the deep wells were supplemented with nine new shallow observation wells (10 to 170 feet deep) located adjacent to the trunk stream (fig. 2).

During the field seasons of 2003, 2004, and 2005, a variety of data were collected in the boreholes and from the watershed, including: (1) basic field geological, fracture network, and fault data as well as rock samples for alteration mineralogy, elemental geochemistry, thin-sectioning for microstructural analyses, and petrophysical studies; (2) infiltrometer measurements in 
representative surficial materials; (3) tracer-dilution test results from the trunk stream; (4)

continuous stream discharge and temperature data for the 2005 water year measured using a stilling well installed in the trunk stream; (5) geophysical borehole-logging data (caliper, optical and acoustic imaging, heat pulse flow meter, temperature, water conductivity, gamma, specific potential, and magnetic susceptibility); and (6) an extensive set of single well hydraulic test data. Ground- and surface-water samples were collected and analyzed for dissolved noble gases (including ${ }^{3} \mathrm{He}$ ), tritium, chlorofluorocarbons, ${ }^{13} \mathrm{C}$ and ${ }^{14} \mathrm{C}$, major and trace elements, and multiple isotopes ( $\mathrm{Sr}, \mathrm{S}, \mathrm{O}$, and $\mathrm{H})$.

\section{Preliminary Results}

Preliminary results of ongoing research in the Handcart Gulch research watershed include the following:

(1) Outcrop observations indicate that the bedrock is complexly deformed and primarily consists of tightly folded felsic and mafic Precambrian metamorphic rocks. Geologic structures include the Montezuma ductile shear zone, cut by a few brittle, small-displacement (on the order of meters to a few tens of meters) faults and high-intensity joint networks. In addition to various regional deformation events, Tertiary porphyry stocks and dikes caused extensive fracturing that is spatially associated with pervasive and disseminated hydrothermal alteration with weak molybdenite and copper mineralization. Other than minor molybdenite and chalcopyrite, the area is largely devoid of base-metal sulfides, and was thus not mined. The dominant alteration assemblage is quartzsericite-pyrite (QSP) characterized by quartz (35-65\%), sericite (15-40\%), kaolinite (0-20\%), and fine-grained pyrite (average 10\%), which has low to no acid-neutralizing potential and high acid- 
generating potential. The intensity of hydrothermal alteration decreases away from Webster Pass and Red Cone peak and transitions outward from QSP to propylitic alteration, then into relatively fresh rocks (figs. 2 and 3). The depth of the pervasive hydrothermal QSP alteration extends to as much as $1000 \mathrm{~m}$ from the ground surface, beneath which rocks are generally more weakly altered (propylitic and superimposed weak argillic alteration). On the basis of the four WP and four HC wells, zones of pyrite oxidation by infiltrating ground waters appear to generally reflect a fracturecontrolled vadose zone, ranging in depth from $100 \mathrm{~m}$ below surface at higher elevations to just a few meters near the base of the study area. Zones of kaolinite and dioctahedral smectite associated with the dissolution of albite, chlorite, and sericite also controlled by acid weathering are revealed in drill cores and extend to depths of several hundred meters. Oxidation of disseminated pyrite in the more intensely hydrothermally altered headwater portion of the watershed creates acid waters with elevated iron and sulfate concentrations. Uplift, erosion, glaciation, and hydrologic processes generated extreme relief and a carapace of weathered bedrock overlain by local alluvium, colluvium, thin soils, an active rock glacier (composed of QSP bedrock debris), and a narrow band of ferricrete in the trunk stream thalweg.

(2) A tracer dilution study (see methodology in Kimball, 1997) was conducted in the upper two kilometers of the trunk stream (fig. 2) to quantify stream discharge and delineate locations of metal loading. As is common in mountain streams, discharge increases in a downstream direction. Acidity also increases downstream. Loading of zinc, aluminum, copper, and sulfate all increase downstream, and zinc and copper concentrations are above aquatic life standards.

(3) Down-hole televiewer and flow meter data indicate there are pervasive and high intensity fracture networks to depth through which high ambient ground-water flow rates occur in the bedrock aquifer, particularly near the trunk stream. Aquifer test results for bedrock hydraulic 
conductivities are considerable, ranging up to $\sim 10^{-6} \mathrm{~m} / \mathrm{s}$, though the percentage of fractures that are clearly hydraulically conductive is small. Therefore, bedrock ground water is a non-trivial component of the hydrologic system.

(4) Up to 43 feet of well-developed ferricrete (iron-oxide-cemented sediments) apparently behaves as a confining unit, resulting in artesian conditions in the bedrock near the trunk stream. Measured static water levels in the bedrock under the stream were up to 9 feet above ground surface. Sustained or seasonal artesian flow occurs in all of the bedrock wells (with a maximum of 20 gallons per minute) in the vicinity of the stream except HCBW4, which is set back about 200 feet from the stream. Because the ferricretes impede ground-water discharge to the stream, much of the bedrock ground water may flow down-drainage underneath the stream, making its discharge location uncertain.

(5) Temperature profiles from the deep WP wells become nearly linear at depths greater than about 300 feet below the water table (greater than about 600 feet below ground surface), suggesting that active ground-water circulation does not exceed these depths. It should be understood, however, that this does not preclude significant ground-water flow on a geologic time scale below these depths.

(6) ${ }^{3} \mathrm{H} /{ }^{3} \mathrm{He}$ ground-water age results indicate increasing ground-water age with depth. Springs near the creek generally discharge shallow-circulating ground water with apparent ${ }^{3} \mathrm{H} /{ }^{3} \mathrm{He}$ ages of $<2$ years. Samples from wells screened in surficial materials (colluvium and ferricrete) have apparent ages of 2-20 years. Samples from bedrock wells have apparent ages of mainly 15-35 years. Artesian flow from the bedrock wells affords the opportunity to collect samples that are naturally flow-weighted. Apparent ages from these integrated samples are relatively consistent along the stream, ranging from 15 to 23 years, the one exception being HCBW1 with an apparent age of 29 
years. The similarity in the ages of the flow-weighted samples is consistent with a relatively simple representation of the flow system in which recharge and circulation depth are constant throughout the drainage. This in turn supports the notion that the watershed can be meaningfully represented with an equivalent porous media model with relatively simple boundary conditions. The concentration of excess (non-solubility) atmospheric gases dissolved in the bedrock waters, termed 'excess air', is typically $20-30 \mathrm{~cm}^{3} \mathrm{STP} / \mathrm{Kg}\left(0\right.$ to $6 \mathrm{~cm}^{3} \mathrm{STP} / \mathrm{Kg}$ being normal), and is among the highest ever observed in a natural system. These exceptionally high excess-air concentrations are consistent with the unusually large water level fluctuations observed in WP wells higher in the watershed noted below. Excess-air concentrations are positively correlated with apparent ${ }^{3} \mathrm{H} /{ }^{3} \mathrm{He}$ age, consistent with older waters recharging farther from the stream where water table fluctuations are greater.

(7) Seasonal water table fluctuations in the upper part of the watershed are very large (up to 150 feet). This may indicate significant seasonal cycles of saturation and oxygenation in the thick vadose zone in the upper reaches of the watershed that may be an important mechanism for the liberation of various chemical constituents produced in pyrite oxidation.

(8) Geological, geophysical, hydrological, and thermal data were used as input for constructing a series of preliminary numerical ground-water flow models. Single well aquifer test data were numerically modeled with MODFLOW (Kahn, 2005) to derive hydraulic conductivities (K) and specific storage values (S) for the surface deposits and bedrock. Model-derived K and S values for the surficial deposits are $\sim 10^{-6}$ to $10^{-5} \mathrm{~m} / \mathrm{s}$ and $\sim 10^{-4}$ to $10^{-3} 1 / \mathrm{m}$, respectively, and values for the bedrock are $\sim 10^{-9}$ to $10^{-6} \mathrm{~m} / \mathrm{s}$ and $\sim 10^{-5}$ to $10^{-4} 1 / \mathrm{m}$, respectively. A coupled heat, mass, and fluid transport finite element model of the watershed has been constructed, and an initial manual calibration of this model has been performed. Successful calibration to observed heads and 
temperatures required permeabilities similar to those derived from the pump test data, decreasing permeability with depth, recharge rates to the bedrock aquifer in the $10-20 \mathrm{~cm} / \mathrm{yr}$ range, and relatively high flow velocities under the stream in the downstream direction (Manning and others, 2004). A watershed-scale finite difference model has also been constructed that has been used in conjunction with stream discharge data and precipitation data from an adjacent watershed to estimate a water budget for Handcart Gulch (Kahn, 2005).

Compilation and analysis of all the data is ongoing as of the writing of this report. It is intended that these data will help contribute to a better understanding of alpine hydrogeology in general and the liberation and fate of acidic, trace-metal-rich waters into the environment at Handcart Gulch and other similar localities.

\section{Data Collection Methods}

The data contained in this report were collected using standard methods. Well locations were mapped from 1:24,000 scale topographic maps and confirmed using a handheld Geographic Positioning System. Lithologic logs were created from direct observations of drill core as it came out of each hole, from cuttings, and supplemented from outcrop observations. Well construction data were determined from pre-drilling design and direct observation and construction of each well during drilling. Water levels were measured directly using electronic tapes. Artesian heads were measured using Polyvinyl Chloride (PVC) pipes fitted to each wellhead, allowing the water to reach its static level. Artesian flow was measured using a stopwatch and graduated bucket from valves in the PVC pipes at a level below static after equilibrium was reached. 


\section{Spreadsheet Data Format, Well Access, and Contact Information}

The raw data from each borehole/well was entered into Excel (a spreadsheet computer program) and formatted with all pertinent information regarding well locations, lithologic logs, hole depths and sizes, well construction information, water level data, flow rates for the artesian wells, well location maps, and the results of modeling of hydraulic test data for derivation of aquifer hydraulic properties. Each data type is organized into tabbed worksheets found at the base of the spreadsheet that can be downloaded by clicking on this link < HandcartWellData.xls $>$; clicking on the Tables, Data File Spreadsheet URL link in the Table of Contents above; or contacting the author directly.

All of the wells are buried with local materials within six inches of the ground surface and secured with a locked well cap. For access to the wells, additional information, questions or copies of this report and spreadsheet file contact Jonathan Caine, U.S. Geological Survey, P.O. Box 25046, MS 973, Denver, CO, 80225-0046 or jscaine@usgs.gov.

\section{Acknowledgments}

This work would not have been possible without the generosity of Dr. Charles S. Robinson of Mineral Systems, Inc. who donated the deep boreholes in the study area for research purposes. Cooperation with the U.S. Forest Service and the Colorado Geological Survey is much appreciated. Numerous field partners conducted and assisted with various types of field work whose time and efforts we greatly appreciate: Briant Kimball, Katherine Walton-Day, Robert Runkel, Richard Wanty, Mike O'Neill, and others. We thank Bruce Smith and Maria Montour of the USGS for constructive reviews of this report. This work was funded by the U.S. Geological Survey's Mineral Resources and Mendenhall Postdoctoral Fellowship Programs. 


\section{References Cited}

Botinelly, T., 1979, Mineralogy as a guide for exploration in the Montezuma District, central Colorado: U.S. Geological Survey Open-File Report 79-1177, 18 pp.

Caine, J.S., 2003, Questa baseline and pre-mining ground-water quality investigation. 6.

Preliminary brittle structural geologic data, Questa mining district, southern Sangre de Cristo Mountains, New Mexico: U.S. Geological Survey Open-File Report 03-280, 31 pp.

Caine, J.S., Bove, D.J., Manning, A.H., and Verplanck, P.L., 2004, Preliminary characterization of geological controls on groundwater flow and solute transport in an alpine hydrothermal metal deposit: Handcart Gulch, Montezuma mining district, Colorado Rocky Mountain Front Range: Annual Meeting, Denver, Colorado, Geological Society of America Abstracts with Programs, v. 36, p. 539.

Johnson, R.H., and Yager, D.B., 2006, Completion reports, core logs, and hydrogeologic data from wells and piezometers in Prospect Gulch, San Juan County, Colorado: U.S. Geological Survey Open-File Report 2006-1030, 32 pp.

Kahn, K.G., 2005, Analysis of the shallow groundwater system in an alpine basin, Handcart Gulch, Colorado: Master of Science Thesis, University of Colorado, Boulder, $150 \mathrm{pp}$.

Kahn, K.G., Caine, J.S., and Ge, S., 2005, Estimating hydraulic properties of complexly fractured and metallically mineralized bedrock in an alpine watershed, Handcart Gulch, Colorado: Geological Society of America Abstracts with Programs, v. 37, n. 7, p. 504.

Kimball, B., 1997, Use of tracer injections and synoptic sampling to measure metal loading from acid mine drainage: U.S. Geological Survey Fact Sheet FS-245-96, 4 pp.

Lovering, T.S., 1935, Geology and ore deposits of the Montezuma Quadrangle, Colorado: U.S. Geological Survey Professional Paper 178, 119 pp.

Manning, A.H., Caine, J.S., Verplanck, P.L., Bove, D.J., and Landis, G.P., 2004, Insights into groundwater flow in an alpine watershed provided by a coupled heat, mass, and fluid transport model, Handcart Gulch, Colorado: Annual Meeting, Denver, Colorado, Geological Society of America Abstracts with Programs, v. 36, p. 539.

Naus, C.A., McCleskey, R.B., Nordstrom, D.K., Donohoe, L.C., Hunt. A.G., Paillet, F., Morin, R.H., and Verplanck, P.L., 2005, Questa baseline and pre-mining ground-water quality investigation. 5. Well installation, water-level data, and surface- and ground-water geochemistry in the Straight Creek drainage basin, Red River Valley, New Mexico, 2001-03: U.S. Geological Survey Scientific Investigations Report 2005-5088, 228 pp.

Neuerburg, G.J., Botinelly, T., and Watterson, J., 1974, Molybdenite in the Montezuma District of central Colorado: U. S. Geological Survey Circular C 0704, 21 pp.

Nordstrom, D.K., McCleskey, R.B., Hunt, A.G., and Naus, C.A., 2005, Questa baseline and premining ground-water quality investigation. 14. Interpretation of ground-water geochemistry in catchments other than the Straight Creek catchment, Red River Valley, Taos County, New Mexico, 2002-2003: U.S. Geological Survey Scientific Investigations Report 2005-5050, 94 pp. 
Robinson, C.S., 1978, Hydrology of fractured crystalline rocks, Henderson Mine, Colo: Mining Engineering, v. 30, p. 1185-1194.

Verplanck, P.L., Nordstrom, D.K., Manning, A.H., Caine, J.S., Plumlee, G.S., Hunt, A.G., and Bove, D.J., 2004, Linking geochemical and hydrologic models of ground water in two Rocky Mountain catchments: Straight Creek, NM, and Handcart Gulch, CO: Annual Meeting, Denver, Colorado, Geological Society of America Abstracts with Programs, v. 36, p. 539. 